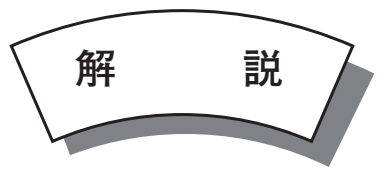

\title{
重工業分野におけるレーザ加工技術の最前線
}

\section{Leading Edge of Application and Innovation with Laser Processing in Heavy Industry}

\section{大 脇 桂* \\ Katsura OOWAKI}

Key Words: Laser Processing, Laser Welding, Underwater Welding, Laser Cladding, Hybrid Welding, Remote Laser Welding

\section{1. 緒 言}

レーザ光を熱源とした溶接・切断・表面改質等の熱加工 に用いるレーザ加工は、低入熱・高精度・高速加工が可能 であることから、幅広い産業分野での適用が期待されてい る。実際に、電機・電子産業における微細加工分野や自動 車の薄板加工分野ではすでに多くの実用化例を見ることが できる。ただし、対象物の板厚が厚くなり、サイズが大き くなると、レーザ発振器の出力と発振効率、対象物の精度 管理とハンドリング、加工そのものの安定性等において解 決すべき課題が存在する。このため、重工業分野における 普及はそれほど多いとはいえない。

しかしその一方で、近年、レーザ発振器のビーム品質・ 出力・信頼性が急速に進歩してきたこと、発振、励起方式 の異なるいくつかのレーザ発振器が高出力レベルでの実用 化を迎えていること、またモニタリングやビーム制御技術 等の周辺技術が進歩してきたことなどから、この技術分野 は新たな段階を迎えつつあることも事実である。

ここでは、レーザ加工分野の技術動向や最新技術とその 適用事例について紹介する。

\section{2. レーザ加工技術の現状}

レーザ加工は通常のアーク熱源を用いた加工と比較し て、イニシャルコスト（設備投資額）が高いため、レーザ でなければ不可能あるいは、信頼性が確保できないという 部材を対象に適用されてきた。以下にこれまでのレーザ加 工事例について述べる。

\section{1 狭隘部・特殊環境への適用}

狭隘部や水中 · 人の近づけない放射線環境下における溶 接では、遠隔・自動溶接が不可欠な技術であり、光ファイ バー伝送が可能なYAGレーザ溶接法は、アーク溶接で問 題となる電圧降下や高電圧伝送を考慮する必要がなく、非 常に有効な手段である。
原子力分野では、高品質の水中溶接技術の要求が高まっ ており、ファイバー伝送可能な大出力固体レーザが従来の 溶接法に変わる新たな溶接法として注目されている。筆者 らは、タンク内面の肉盛補修溶接や原子炉内構造物の表面 改質へ水中 YAG レーザ溶接法を適用した。

Fig.1に水中 YAG レーザ溶接法の原理を示す。溶接へッ ド内には、レーザビームとシールドガスが同軸で供給され ており、被溶接部はこのシールドガスによって部分的に気 中雲囲気になっている。遮水の構造は極めてシンプルであ るが、この方法で十分なシールド法を確保できる。水中に おけるビードの形成はシールドガス流量、溶接速度、ノズ ル高さおよびノズル穴径などによって影響される。これら を適切に選択することで安定した溶接が可能となる。

Fig.2 は、水中レーザ溶接を行うための溶接ロボットの 外観模式図である。本溶接ロボットを用いた母材部及びす み肉継手への補修溶接施工法は、特殊方法溶接として、経 済産業省より認可されており、実機工事に即時投入が可能 である。

2.2 素材機能化

素材に新たな機能を付加する表面改質においても、レー

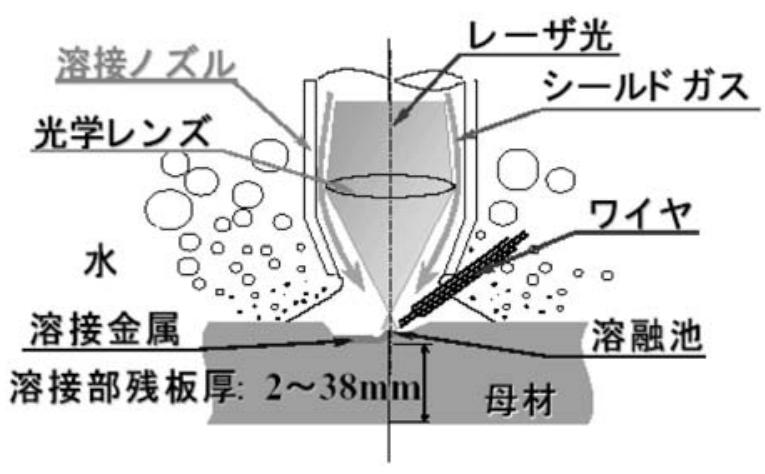

Fig.1 Underwater laser welding.

* 株式会社 IHI 検査計測（ $\mathrm{T}$ 235-8501 横浜市磯子区新中原町 1)

IHI Inspection \& Instrumentation Co., Ltd. (1 Shin-nakahara-cho, Isoko-ku, Yokohama 235-8501 JAPAN) 


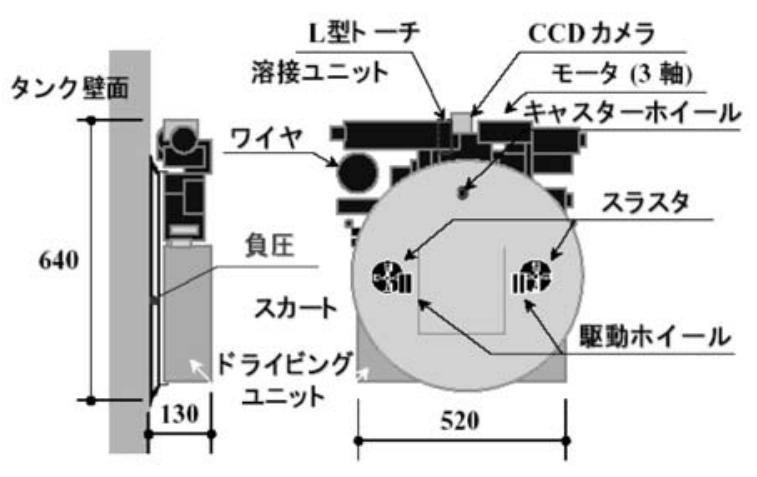

Fig.2 Remote tool for underwater laser welding.

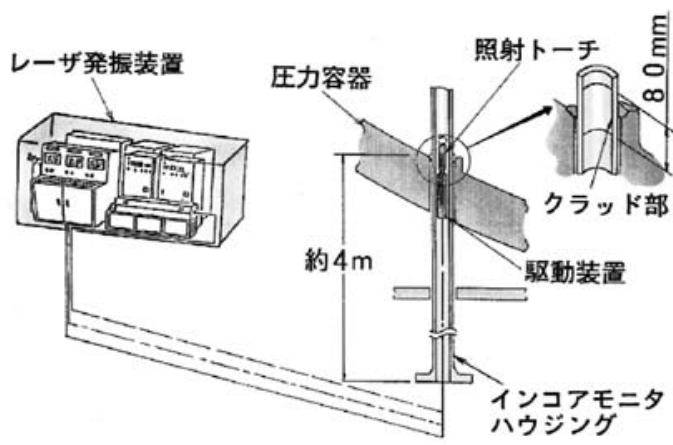

Fig.3 Laser cladding system for ICM guide tube.

ザ加工技術は素材への熱影響が小さいという点で非常に有 効な手段である。ここでは、高い信頼性と安全性を要求さ れる原子力プラントでの実用化例について述べる ${ }^{1) 。 ~}$

2.2.1 原子炉 ICM 配管へのレーザクラッディングの適用

原子力プラントでは年一回の定期検査が義務づけられて おり、ここで補修あるいは予防保全対策が必要とされたも のについては、現地にて信頼性の高い技術を用いて効率的 に作業を進めることが要求される。

過去にBWR（沸騰水型原子炉）に㧍いて、予防保全の 観点から、既設ステンレス小口径配管（インコアモニタハ ウジング）の溶接部内面に㧍ける応力腐食割れ性を改善し たいというニーズがあった。この狭湓部に対する工法とし て、YAGレーザを用いて高耐食性合金を配管内面にクラッ デイングする技術を開発、実用化した。Fig.3に本工法の概 要、Fig.4にクラッディング部の外観を示す。屋外から光ファ イバーにて伝送されたレーザ光により、既設配管内面に予 め塗布された高耐食性合金粉末層を溶融し、高耐食性合金 層を形成させる。予防保全対策としての本技術は、既設プ ラントの寿命延長を可能とした。

2.2.2 熱交換器フランジシール面へのレーザクラッディン グの適用

炭素鋼熱交換器フランジシール面では、ガスケット面に

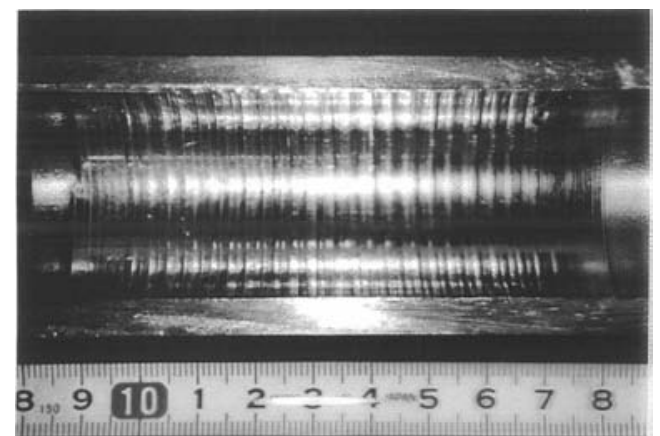

Fig.4 Bead appearance of laser cladding.

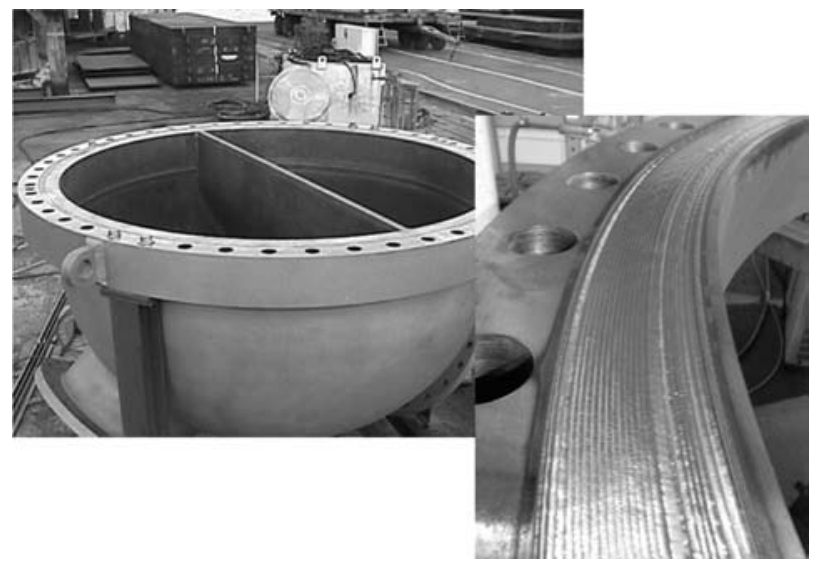

Fig.5 Flange surface of heat exchanger with carbon steel.

孔食が発生しやすく、この部分に対する恒久対策としてス テンレス鋼のレーザクラッディングを実施した。対象部材 は Fig.5 に示すような外径約 $1800 \mathrm{~mm}$ のフランジで、肉盛 幅 $60 \mathrm{~mm}$ の大面積をクラッデイングする必要がある。シー 儿面であることから変形を極力抑える必要がある。そこで、 レーザクラッディングを採用することとした。本工法では 母材による希粕を極力抑元、かつ初層の炭素鋼成分による 硬化を 2 層目のクラッディングにより再熱することで、施 工後の熱処理を省略することも可能とした。

\section{3 高精度・低入熱溶接}

自動車、電機産業、重工業分野などで金属材料の溶接や 切断加工において、高出力のファイバーレーザやディスク レーザの適用が拡大している。これまで大出カレーザの代

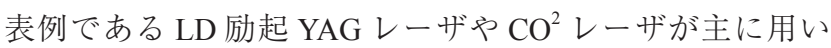
られてきたが、コストや性能面で劣っているのが現状と言 える。現在盛んに使用されつつあるファイバーレーザは、 これまで高出力が困難であると考えられてきたが、現在で は $20 \mathrm{~kW}$ の出力を持った発振器がラインナップされてい る。産業界では、自動車分野や橋梁、造船などの構造部材 に適用されつつある。各メーカから販売されている発振器 


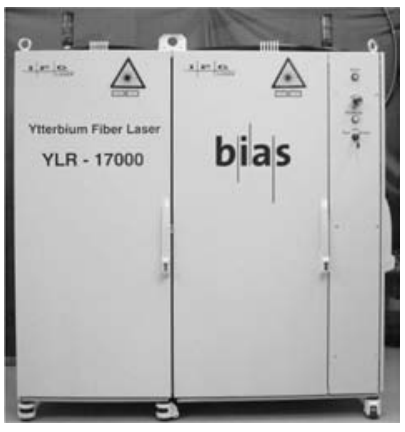

$17 \mathrm{~kW}$ fiber laser

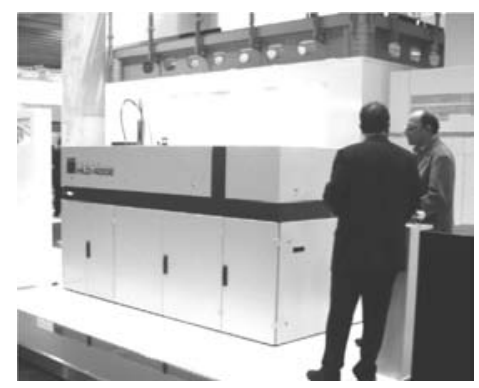

$4 \mathrm{~kW}$ disk laser

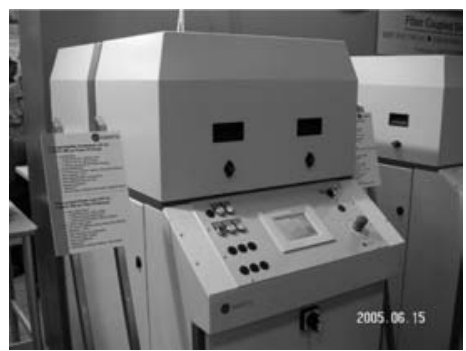

$10 \mathrm{~kW}$ diode laser

Fig.6 Several types of high power laser sources.

をFig.6に示す。対象としては、構造部材への適用を目標 として、ファイバーレーザを用いたレーザ溶接やアーク溶 接を併用したハイブリッド溶接の研究開発を進めている。

\section{3. レーザ・アークハイブリッド溶接現象とその適用}

レーザ・アークハイブリッド溶接（以下、ハイブリッド 溶接）は、Fig.7に示すように、レーザとアークの熱源で 一つの溶融池を形成させ、レーザ溶接とアーク溶接の両方 を組み合わせた溶接方法である。レーザとアークの特徵

を活かし、さらに、ハイブリッド化により生じるさまざ まな特徵を生かした新しい溶接方法としての研究・開発が 行われ、現在では実用化を含めて各方面で利用されている。

ここでは、ハイブリッド溶接の装置構成や特徵及び溶接 現象を観察した一例について述べるとともに、現在実用化 またはそれに向けて適用が検討されている例について紹介 する。

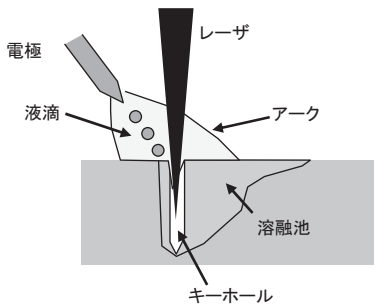

(a) Leading arc

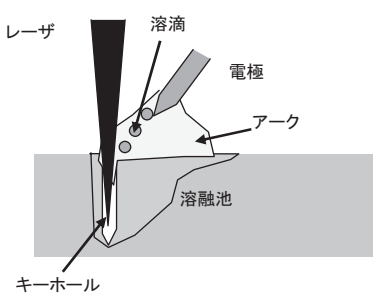

(b) Leading laser
Fig.7 Hybrid welding process principles.

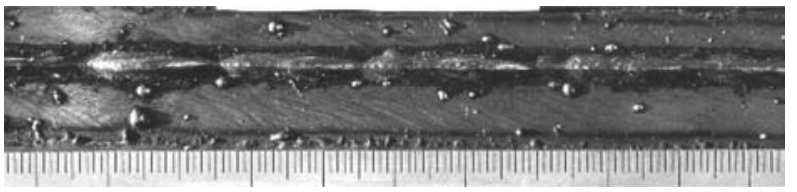

(a) GMA welding

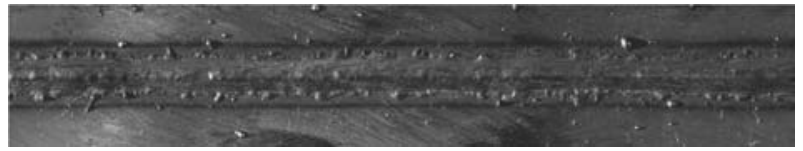

(b) Hybrid welding

Fig.8 Bead appearances of laser arc hybrid welds.

3.1 レーザ・アークハイブリッド溶接装置の構成

レーザ・アークハイブリッド溶接装置は、レーザ溶接に 使用するレーザ発振器と、市販されているアーク溶接用の 電源を組合せ、レーザヘッドにアーク溶接用のトーチを装 着させて行うことが、一般的である。

ハイブリッド溶接に使用するレーザ発振器は、通常の レーザ溶接と同様の発振器から選択される。この中でも、 光ファイバーでレーザを伝送できるファイバーレーザや デイスクレーザなどが操作性の面から有利であり、採用さ れることが多い。特にファイバーレーザは従来のレーザと 比較して発振器の大きさが小さく、また、高効率であるこ と、高ビーム品質が得られることから、従来のレーザ以上 に高速溶接や、深溶込み溶接が可能となった。この性能が 期待され、各分野で研究開発が活発に展開され、一部では 実用化が始まっている。ハイブリッド溶接でも、このファ イバーレーザへの期待は高く、多くの研究開発が実施され ている ${ }^{2)}$

Fig.8 及び Fig.9 にハイブリッド溶接におけるビード外観 と断面マクロ観察結果の一例を示す。

\section{2 レーザ・アークハイブリッド溶接の最近の適用}

薄板に対しては、寸法精度の向上とともに高速溶接が行 える点と継手特性の面で溶込み深さや溶着量を増やすこと が出来る点などから、これら施工性が必要である個所に適 


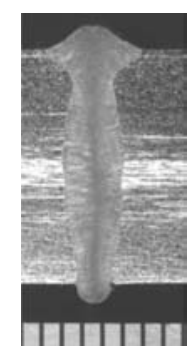

(a) Laser welding

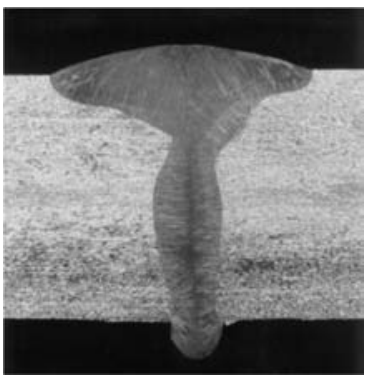

(b) Hybrid welding
Fig.9 Cross sections of laser and hybrid weld beads.

用が進められている。その一つとして、自動車分野では、 ドア部分へのレーザ・アークハイブリッド溶接の適用が行 われて㧍り ${ }^{3)}$ 、そのほかテーラードブランク材やアルミ材 への検討も行われている ${ }^{4)}$ 。

厚板に関しては、変形が少なく後工程の仕上げ調整や組 立工数の削減がメリットとなる。ヨーロッパでは、造船用 部材の隅肉溶接や、突合せ溶接にハイブリッド溶接が実用 化されている。また、ギャップ裕度拡大と継手特性の改善 を目的に、パイプの全姿勢溶接などへの適用も検討されて いる ${ }^{5)}$ 。

\section{3 自動化への動向}

ハイブリッド溶接は、アーク溶接条件やレーザ溶接条件 などのパラメータが多く、また、レーザ溶接を用いる特性 上、自動化が不可欠である。基本的には、複雑な溶接線や 比較的小型な部材には、多関節ロボットが多く用いられ、 直線の溶接には、精度に優れたカンチレバータイプやガン トリータイプの装置が多く用いられる。また、大型構造物 を溶接する場合、大型の装置が必要となるが、コスト面か らの制約も大きくなる。このような観点から、走行台車を 用いたハイブリッド溶接装置の開発がヨーロッパで行われ ており、著者らも、溶接装置を開発し、良好な溶接継手を 得ている。Fig.10にカンチレバータイプのハイブリッド溶 接装置を Fig.11に走行台車方式の溶接装置を示す。また、 このような大型部材を溶接する場合には、狙い位置精度や 溶接変形などの観点から、開先倣い機構を用いた溶接装置 の開発が必要となる。

\section{4. リモート溶接とその適用}

高品質なレーザビームが得られる発振器を使用すること により、近年、リモートレーザ溶接が盛んに研究されて いる。リモート溶接とは、従来レーザマーキング装置で使 用されていたガルバノスキャナーに高出力で高品質なレー ザビームと長焦点のレンズを組み合わせて、レーザビーム をある溶接個所から別の溶接個所に瞬時に移動させること ができる装置である。これによって、これまで時間を費や

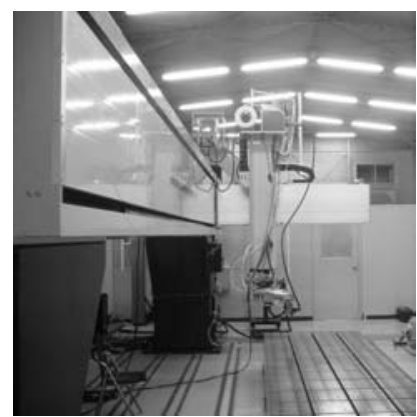

Fig.10 Cantilever welding machine.

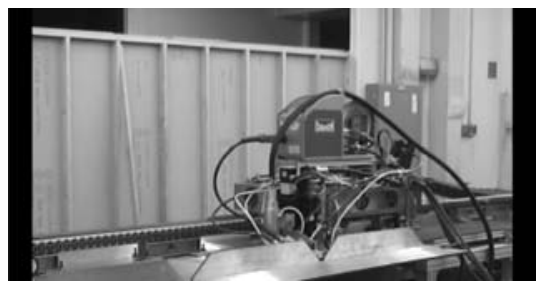

Fig.11 Automated guided vehicle system.

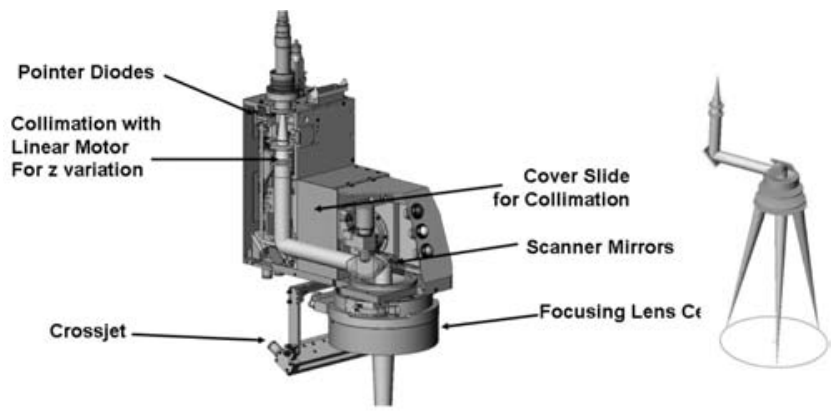

Fig.12 Scanner head for remote laser welding.

していた溶接個所の移動時間を飛躍的に短縮することがで き、また、広範囲な領域を溶接することができるため、加 エヘッドを移動させることなく、多くの点数を短時間で溶 接することが可能となる。溶接部の信頼性向上や生産ライ ンの設備のスペースを大幅に簡略化することにより、今後、 品質向上とコス卜低減のための有望なツールとして期待で きる。以下では、リモート溶接技術の適用例を紹介すると ともに、溶接品質を確保するために必要不可欠なインプロ セスモニタリングシステムの開発状況について述べる。

4.1 リート溶接の原理とシステム

Fig.12にリモート溶接の原理を示すの。レーザ発振器か ら出されたレーザビームは集光レンズを介して、専用のス キャニングミラーで反射されてワークに照射される。通常 焦点距離は $1 \mathrm{~m}$ 程度の長焦点レンズを使用する。スキャニ ングミラーは一枚で直交 2 軸を駆動することができ、 Z 軸 

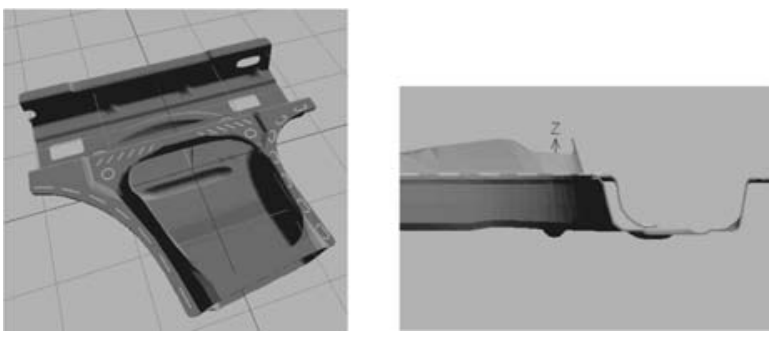

Fig.13 Application for automotive bodies.

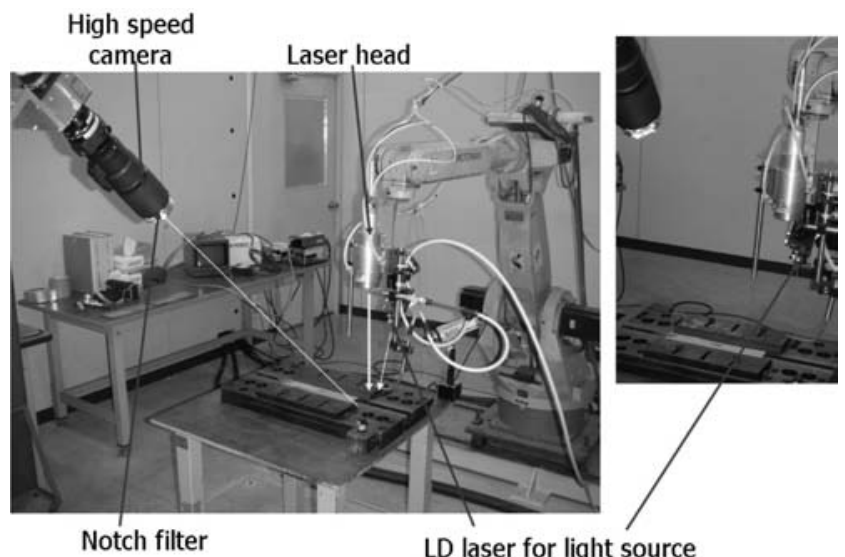

Fig.14 Photographic device used for the long stand-off of the focusing head.

方向にも集光点を連続的に移動させることができる。ま た、従来のロボットなどの搬送装置を使用した加工と比較 して、高速移動及び正確な位置決めが可能である。これに より、溶接個所の移動時間は数十 $\mathrm{ms}$ オーダーであるため、 移動時間を最小にすることができ、単位時間あたりの溶接 ポイントを増加させるなど高生産性を実現させることがで きる。

\section{2 リモート溶接の適用例}

リモート溶接は主に自動車車体や自動車パーツの製造に 向けた研究開発が行われている ${ }^{7)} 8$ 。Fig.13に示すように 自動車車体は薄板構造体の典型であり、数百種類の鋼板プ レス部品を溶接にて一体化させた、スチールコック構造が 一般的である。溶接法としては、従来、抵抗スポット溶接 が $90 \%$ を占めており、車 1 台当たりの打点数は 4,000～5,000 点に及ぶ。このため、数十台のロボットを同時に使用し、 溶接時間の短縮化を図っているが、多数の溶接ロボットを 設置するためにそのための設備や工場面積が必要となる。 リモート溶接技術を用いることにより、広い範囲を 1 台の レーザ溶接機でほぼ同時に溶接することができる。

このように、リモート溶接では、溶接部から溶接部への 移動時間が他の溶接法と比較して極めて短く従来のロボッ

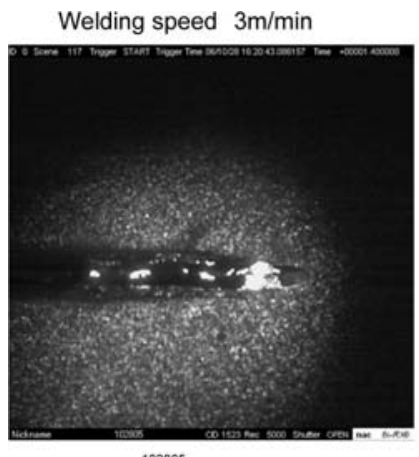

102805
Welding speed $5 \mathrm{~m} / \mathrm{min}$

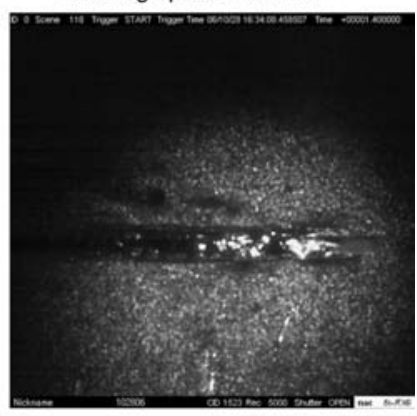

102806
Fig.15 Images by the long stand-off of the focusing head.

トを使用した溶接と比較して精度の良い位置決めが可能で あるため、多数の溶接個所がある部材や複雑形状を有する 部位へ適用することにより、大幅なコスト削減が期待でき る。このような観点から重工業分野では、管と管板などの シール溶接など複雑形状への適用が試みられている。

4.3 リート溶接のモニタリングシステム

レーザ溶接部の品質保証を行う場合、溶接中に溶接部を 観察（インプロセスモニタリング）し、溶接品質の良否判 定システムが必要となる。ここでは、新たに長焦点のレー ザビームで形成される溶融池をモニタリングする装置開発 への足がかりとして、長焦点距離で観察することを確認す るための基礎試験を行った。ワークとモニタリング装置の 距離を $1 \mathrm{~m}$ として溶融部の挙動を撮影した。Fig.14にモ二

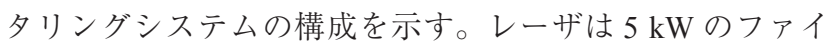
バーレーザを使用し、加工ヘッドの焦点距離 $450 \mathrm{~mm}$ の加 エヘッドを使用した。照明用の補助光源として、波長 980 $\mathrm{nm}$ 、最大出力 $30 \mathrm{~W}$ の半導体レーザを用いている。また、フィ ルターとして、波長 $974 \mathrm{~nm}$ のバンドパスフィルターを高 速度カメラに装着した。撮影速度は $5000 \mathrm{~F} / \mathrm{s}$ とした。

Fig.15にレーザパワー $3 \mathrm{~kW} て ゙$ 照射した場合の観察結果 例を示す。観察結果から、補助光源を使用することにより、 撮影距離約 $1 \mathrm{~m}$ において、溶接中の溶融プールの状況及び スパッタの形成を明瞭に観察することができた。

現在、本システムをリモート溶接加工ヘッドに装着し、 高速に移動するレーザビームと同期した溶融池のインプロ セスモニタリングシステムを開発中である。リモート溶 接では、加工ヘッド内のミラー角度を変えることにより、 レーザビームの照射位置を制御している。本システムでは、 Fig.16に示すように、長焦点距離の CMOS カメラを装着し、 ダイクロイックミラーを使用することにより高速に移動す るレーザビームと同期する。加工点の観察状況を Fig.17に 示す。本インプロセスモニタリングシステムを使って、レー ザ溶接中に溶接部を観察することにより、溶接品質の良否 を判断することが可能となる。 


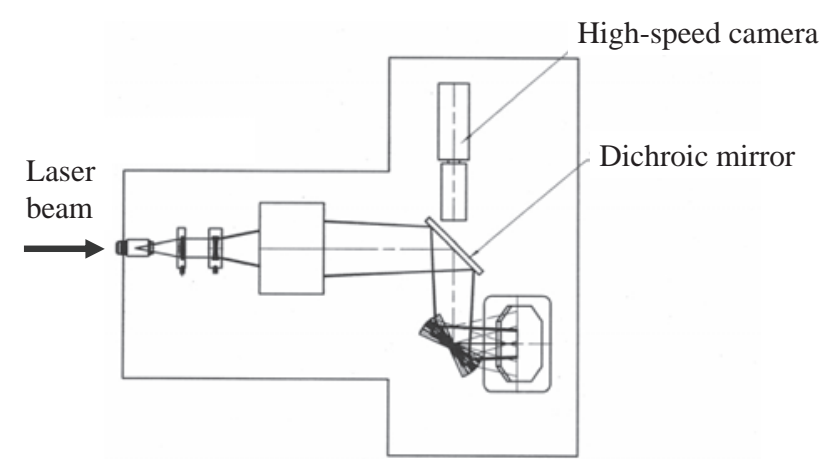

Fig.16 Schematic set-up of in-process monitoring system.

\section{5. まとめ}

レーザ溶接では、材質や板厚、ユーザの必要とする生産 タクトに合わせた最適な熱源を選択する必要がある。その 中でも、近年開発が進んでいるファイバーレーザやディス クレーザまたは、高出力半導体レーザなど最適な熱源を使 用することにより、生産プロセスとしての革新が図れるも のと期待できる。

\section{引用文献}

1) 大脇ら：“最近のレーザ・アークハイブリッド溶接現象とその 適用”、平成 19 年度溶接技術講習会（社）日本溶接協会中国支

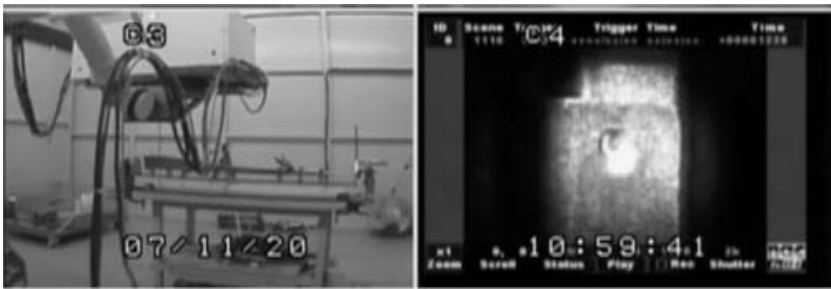

Fig.17 Monitoring result of high-speed observation image.

部)、(2007) 63-74.

2) 大脇ら：“重工業分に扔けるレーザ加工技術の現状と今後”、 溶接学会レーザフォーラム (2004), (2004) 16-20.

3) 阿部、林：“レーザ・アーク複合溶接法とその将来”、溶接技術、 51-7 (2003) 62-67.

4) 河合、岩見、馬場、小川："レーザ・アークハイブリッド溶接 現象の観察”、第 153 回溶接アーク物理研究委員会資料、ア物 $-04-1218$.

5) 村山、外館：“パイプのレーザハイブリッド全姿勢溶接”、溶 接技術、54-4 (2006) 52-59.

6) 水谷：“レーザ加工ヘッドの最新動向及びその適用例”、LMP シンポジウム 2008、(2008) 139-146.

7) 空田：“自動車業界に佂けるリモート溶接について”、第 68 回 レーザ加工学会講演論文集、(2007) 147-150.

8）樽井、森ら：“車体へのレーザ溶接適用技術”、第 68 回レーザ 加工学会講演論文集、(2007) 157-163. 